\title{
Allies in Music: French influence and role models in the Cvijeta Zuzorić Association of Friends of Art
}

\author{
Srđan Atanasovski
}

In the interwar period, France was seen as the main military and diplomatic ally of the Kingdom of Serbs, Croats and Slovenes (SCS), later Kingdom of Yugoslavia, and the defender of the fragile Versailles Peace Treaty. This relationship resulted in a clear French influence in the realm of art and culture in Yugoslavia. Moreover, the triumph of the French cultural influence was also interpreted in the light of the simmering conflict between Serbian and Croat elites in Yugoslavia, as Serbian intellectuals traditionally gravitated toward Paris and France, unlike the Croat (and Slovene) ones, which had been part of the Central European and Austro-Hungarian cultural sphere. This article analyzes the French cultural influence through the musical activities of the Cvijeta Zuzorić Association of Friends of Art. The organization was established to promote modern art and the endeavors of young artists. It was firmly latched onto various mechanisms of state support, and participated in promoting the dominant ideology of the Karađorđević royal dynasty. The paper follows the association's musical activates through its three phases: the initial period, marked by annual artistic soirees, the middle period and the activities of the Narodni konzervatorijum (National Conservatory), which included weekly concerts of varying quality, and the final period of open music competitions. The article maps a clear picture of French artistic influences, which notably included open modeling of certain commissioned and awarded compositions on famous French pieces.

\section{France as an ally in politics and culture}

Throughout the interwar existence of Kingdom of SCS/Yugoslavia, the state was riven with internal political struggles and external European geopolitical instabilities. ${ }^{1}$ Born out of the WWI and the military victory of the allies and the Serbian army, the Kingdom of SCS was hastily proclaimed on December 1, 1918, at the official meeting between a delegation of the National Council of the State of Slovenes, Croats and

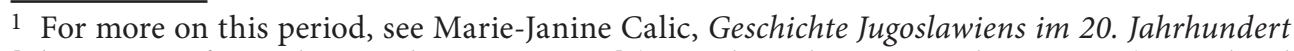
[The History of Yugoslavia in the $20^{\text {th }}$ Century] (Munich: Verlag C. H. Beck oHG, 2010), translated into Serbian as Mari-Žanin Čalić, Istorija Jugoslavije u 20. veku (Belgrade: Clio, 2013), 103-119. 
Serbs, formed on the southern Slavic territories of the defeated Austria-Hungary, and regent Alexander Karađorđević, representing the Kingdom of Serbia and its King Peter I. The newly formed Kingdom of SCS participated at the Paris Peace Conference in the following year, affirming its position as one of the main actors in the Balkans and securing its territory to clear dissatisfaction of many of its powerful neighbors, including Italy, Austria and Hungary. However, the kingdom's internal disputes were not resolved in Pairs, and continued well into the interwar period, even after the process of adopting a constitution was completed in 1921. These disputes can be summarized in three main, significantly overlapping issues - national, federal and dynastical - and the dividing lines were most strongly pronounced between the Serbian and Croatian political and economic elites. The main question, which can be felt throughout the interwar Yugoslav political landscape, is whether Serbs, Croats and Slovenes are three separate nations joining in a political union, or merely "tribes" of a single "integral" Yugoslav nation (hence integral Yugoslavism). ${ }^{2}$ Bearing in mind that the European interwar period was formative for the doctrine of nation-state sovereignty and dominated by primordial and racial interpretations of the nation, the importance of this question cannot easily be overemphasized. This issue is closely followed by deliberation on the internal governance of the kingdom, with the dilemma between a centralized system and a federal framework, where the separate nations would govern their respective historical or ethnic territories. Finally, a significant share of Croatian politicians contested the position of the Serbian royal dynasty, and demanded a discussion on the possibility of establishing a republican rule.

The resulting political turbulences-including political assassinations, terrorist actions, a period of dictatorship, federal restructuring, etc.- did not, however, take place in a vacuum, but in a context of perpetual contestation of the Versailles Treaty throughout the interwar period in Europe. The diplomatic alliances that Yugoslavia formed in the interwar period were thus reflected in the sphere of tempestuous internal politics. Overall, France was seen as the principal guardian of the Versailles Treaty, which countries like Germany, Italy and Hungary tried to subject to revision. The alliance with France, as well as other alliances supported by France, such as the Little Entente (with Czechoslovakia and Romania), were a major centripetal force in Yugoslav politics. Moreover, the French cultural and artistic influence immediately after the WWI was seen as a direct result of this fruitful alliance, since a significant part of artists and intellectuals had spent the war years in Paris. Therefore, the cultural influences of France throughout the interwar period were seen as an expression of friendship with a powerful protector. ${ }^{3}$

2 Cf. Jovo Bakić, Ideologije jugoslovenstva između srpskog i hrvatskog nacionalizma 1918-1941: sociološko-istorijska studija [The Ideologies of Yugoslavism between Serbian and Croatian Nationalism 1918-1941: A Sociological-Historical Study] (Zrenjanin: Gradska narodna biblioteka “Žarko Zrenjanin,” 2004).

3 Ljubodrag Dimić, Kulturna politika u Kraljevini Jugoslaviji: 1918-1941 [Cultural Policies in the Kingdom of Yugoslavia] (Belgrade: Stubovi kulture, 1997), Vol. 3, 186-187. 
The French influence was also interpreted in the context of the internal political divisions as a country amicable to the Serbian intelligentsia, as well as its political and economic elite. Besides France being the main military ally of the Serbian forces during the war, Serbian intelligentsia gravitated to France and Paris as a place of education, and was imbued by French cultural and artistic models, unlike their Croat and Slovene counterparts, who-as former citizens of AustriaHungary-were drawn toward the cultural centers of the German-speaking Central Europe. ${ }^{4}$ As Ljubodrag Dimić argues, the promotion of the French avant-garde and impressionism in painting was directly opposed to the academicism permeating the Viennese and Munich schools. ${ }^{5}$

\section{The Cvijeta Zuzorić Association of Friends of Art}

The Cvijeta Zuzorić Association of Friends of Art (Udruženje prijatelja umetnosti Cvijeta Zuzorić) was established in Belgrade in 1922 on the incentive of Branislav Nušić, a prominent Serbian writer and head of the Arts Department at the Ministry of Education. ${ }^{6}$ The task of the association was to draw public attention to the local artistic production, and especially attract the Belgrade middle and upper classes to support high art. ${ }^{7}$ The founders aspired to encourage interest in art and "create the conditions for its progress and development among our people." 8 The idea was for the Cvijeta Zuzorić Association to be run by the wives of prominent Belgrade politicians, which would bring considerable social capital and draw sponsorship for modern art from the Belgrade financial elite, including the royal family. However, this arrangement also resulted in strong and unambiguous influence of state cultural policies throughout the association's existence, which seems to have been particularly pronounced in its musical activities. ${ }^{9}$ For example, the association

\footnotetext{
4 See Milosav Janićijević, Stvaralačka inteligencija međuratne Jugoslavije [The Creative Intelligentsia of Interwar Yugoslavia] (Belgrade: Institut društvenih nauka, Centar za sociološka istraživanja, 1984), 100-112.

5 Dimić, Kulturna politika, 190.

6 For details on the Cvijeta Zuzorić Association, see Radina Vučetić, Evropa na Kalemegdanu. "Cvijeta Zuzorić" i kulturni život Beograda 1918-1941 [Europe in Kalemegdan. "Cvijeta Zuzorić" and the Belgrade Cultural Life] (Belgrade: Institut za noviju istoriju Srbije, 2003).

7 Cf. Peđa J. Marković, Beograd i Evropa 1918-1941. Evropski uticaji na proces modernizacije Beograda [Belgrade and Europe 1918-1941. European influences on the process of Belgrade's modernization] (Belgrade: Savremena administracija, 1992), 179.

8 Historical Archive of the City of Belgrade [Istorijski arhiv Beograda (IAB)], Cvijeta Zuzorić Association of Friends of Art [Udruženje prijatelja umetnosti Cvijeta Zuzorić (CZ)], 3a.

9 Cf. Ivana Vesić, Konstruisanje srpske muzičke tradicije u periodu između dva svetska rata [Constructing the Serbian Musical Tradition in the Period between the Two World Wars] (Belgrade: Muzikološki institut SANU, 2018), 23, 110-123; Srđan Atanasovski, "Muzička delatnost Udruženja prijatelja umetnosti Cvijeta Zuzorić u kontekstu kulturne politike Kraljevine Jugoslavije [The
} 
regularly organized events promoting a shared Yugoslav and pan-Slavic identity and fostering cultural ties within the country, as well as events that were in accordance with the kingdom's foreign policy.

With respect to its musical activities, the history of the association can be divided into three periods: the first one covers the initial period dominated by artistic charity soirées, the second encompasses the activities of the National Conservatory launched in 1925 and maintained until 1932, and the third period includes open competitions for new Yugoslav musical compositions, organized between 1934 and 1941. The first period is characterized by irregular musical activity and frequent cooperation with the literary and visual arts section of the association. Musical performances were thus often held as part of artistic soirées, matinées or exhibitions. The association's pronounced openness and proclivity toward modernism in art was clearly established in these initial activities, and one of the flagship events in this period was the artistic soirée entitled Hiljadu i druga noć (The Thousand and Second Night), fashioned after surrealist avant-garde soirées held in Paris.

The society launched the National Conservatory in 1925 as a regular series of concerts meant to enrich the musical life in the capital. The concerts usually took place twice per month, they varied in content and quality, and often had educational purposes. As the quality started declining (especially after 1929), and the Belgrade musical life became richer, the management felt this was not the real purpose of the organization, and closed National Conservatory with the 1932 season. The music section of the association opted to organize funding competitions for new Yugoslav compositions on an annual basis as a better way of fostering modern music production by young composers. In the period between 1934 and 1941, they conducted five competitions, awarding monetary prizes to the best compositions submitted, and holding concerts of laureates' pieces, styled as festivals of Yugoslav music. The inaugural competition of 1934-1935 was open for new symphonic pieces. In 1936 and 1940, they invited composers to submit chamber music. In 1938, they held an opera competition. And the final edition in 1941 awarded the best new Yugoslav art songs. The association remained active until German occupation in 1941, when it decided to close its doors, to the resentment of the occupying forces.

Modeling after eccentrism:

Satie's Parade and Milojevićs Sobareva metla

Of all the musical works premiered or created at the instigation of the Cvijeta Zuzorić Association of Friends of Art, the ballet Sobareva metla / Le balai du valet

musical activity of the Cvijeta Zuzoric Association of Friends of Art in the context of the cultural policy of the Kingdom of Yugoslavia]," in Likovi i lica muzike, edited by Ivana Perković-Radak, Tijana Popović-Mlađenović (Belgrade: Fakultet muzičke umetnosti, 2010), 207-224. 
(The Servant's Besom) by Miloje Milojević (to a libretto by poet Marko Ristić, and with Klaudija Isačenko and Jelena Poljakova as the original choreographers) has been attracting the greatest attention of music scholars for decades. This ballet indeed represents a sort of excursion both in the oeuvre of Milojević himself as well as the musical landscape of interwar Belgrade in general. Music scholars have analyzed the progressive, avant-garde style used by Milojević, emphasizing particularly the collage structure of the music, polystylism, use of non-musical sound elements (such as a gunshot) and musical references ranging from Richard Wagner to popular music, which all serve to draw clear parallels to the ballet Parade by Eric Satie and Jean Cocteau, produced by Sergei Diaghilev's company Ballets Russes in Paris in 1917. ${ }^{10}$

The political and social frictions immediately after the WWI created the specific cultural and artistic landscape that this work is inextricably linked to. Writer and literary critic Milan Bogdanović used the term "post-war modernism" at that time, and it may serve well to explain this phenomenon. Bogdanović notes that "after the war modernism has all been in a certain state of exaltation, in ecstasy, a delirium. It is not reformist, but wants to be destructive, which has given it the apparent character of a revolutionary literary event." 11 The end of the war and the final realization of the national idea of liberation and unification also served as a significant impetus for the development of modernist orientations. In the years immediately following the war, Belgrade was ruled by a kind of "explosion of novelties" in virtually all segments of city life, especially in the field of education, culture and art. ${ }^{12}$ With the final "vindication of Kosovo," the national myths became redundant as the basic inspiration of artists, who were seemingly free to reject collectivist, national paradigms and turn to

\footnotetext{
${ }^{10}$ See Marija Masnikosa, "Funkcija muzičkih simbola u kompozicijama Smrt majke Jugovića i Sobareva metla Miloja Milojevića" [The function of musical symbols in the compositions Smrt majke Jugovića and Sobareva metla by Miloje Milojević], in Izuzetnost i sapostojanje, edited by Miško Šuvaković (Belgrade: Fakultet muzičke umetnosti, 1997), 140-145; Biljana Milanović, "Sobareva metla: bliskost s evropskom avangardom [Sobareva metla: closeness to the European avant-garde]," in Kompozitorsko stvaralaštvo Miloja Milojevića, edited by Melita Milin, Vlastimir Peričić (Belgrade: Muzikološki institut SANU, 1998), 262-277; Jelena Arnautović, "Korak ispred vremena: dijalog Miloja Milojevića sa francuskim neoklasicizmom u baletu Sobareva metla [One step ahead of time: Miloje Milojevićs dialogue with French neoclassicism in the ballet Sobareva metla]," in Tradicija kao inspiracija, edited by Sonja Marinković, Sanda Dodik (Banja Luka: Akademija umjetnosti, 2010), 72-86.

${ }^{11}$ Milan Bogdanović, "Slom posleratnog modernizma [The collapse of post-war modernism]," Danas 3 (1934): 300-311.

12 Katarina Tomašević, "Prividni ili stvarni sukob Starog i Novog (vidovi sapostojanja tradicionalnog i modernog u srpskoj muzici između dva svetska rata) [Apparent or real conflict between the Old and the New (the types of coexistence of the traditional and the modern in Serbian music between the two World Wars)]," in Izuzetnost i sapostojanje, edited by Miško Šuvaković, 103-104; cf. Katarina Tomašević, Na raskršću Istoka i Zapada. O dijalogu tradicionalnog i modernog u srpskoj muzici (1918-1941) [At the crossroads between the East and West. On the dialogue of the traditional and the modern in Serbian music] (Belgrade, Novi Sad: Muzikološki institut SANU, Matica srpska, 2009).
} 
the "art for art's sake" poetics. ${ }^{13}$ Post-war modernism also represented the aspirations of artists to secure appropriate recognition and place in the society for their art, as there was a general aspiration within the ruling class and elites in post-war Belgrade to revive the cultural life and professionalize artistic fields. ${ }^{14}$

Encouraging modernism could also have been an important tool of cultural policy in the hands of the regime, with the aim of homogenizing and denationalizing the cultural and artistic scene in the spirit of integral Yugoslavism. As already discussed, immediately after the war and still in the process of constituting a common state, the ideology of Yugoslavism was perpetually challenged. As Branka Prpa concludes, even in the ranks of the Serbian intelligentsia, especially in the Belgrade circles, and as early as around 1923, there was strong skepticism about the idea of Yugoslav unity. ${ }^{15}$

Articulating a demand to be included in the currents of European culture and art, the proponents of modernistic tendencies often made clear statements by adopting the most avant-garde acts of their European contemporaries as their role models. Not surprisingly, this was prone to ridicule. In the words of painter Radoje Marković from the mid-1920s: "In our country, the intellectual leadership was inspired by ready-made ideas from other environments." 16 Vasa Pomorišac also commented that "our artists took, without consideration, everything that the West, i.e. Paris, declared modern." 17 The origin of these models and "readymade ideas," however, was not accidental-they were overwhelmingly of French provenance. Thus, for example, the Dadaist/Surrealist literary movement (writers such as Aleksandar Vučo, Milan Dedinac, Marko Ristić, etc.) was completely under the French influence and closely followed the developments in Paris. ${ }^{18}$ Miloje Milojević also spent the WWI in Paris in direct contact with the newest achievements in French music. ${ }^{19}$

The annual artistic soirées were a mechanism through which the Cvijeta Zuzorić Association positioned itself on the cultural scene of the capital and collected the first significant financial resources for the construction of its Art Pavilion.

\footnotetext{
${ }^{13}$ Branka Prpa-Jovanović, "Jugoslavija kao moderna država u viđenjima srpskih intelektualaca 1918-1929" [Yugoslavia as a modern state in the views of Serbian intellectuals 1918-1929] (PhD diss., Univerzitet u Beogradu, 1995), 423; cf. Branka Prpa, Srpski intelektualci i Jugoslavija: 1918-1929 [Serbian Intellectuals and Yugoslavia: 1918-1929] (Belgrade: Clio, 2018).

14 Jelena Milojković-Đurić, "Muzika kao deo srpske kulture u periodu između dva svetska rata [Music as a part of Serbian culture in the period between the two World Wars]," (PhD diss., Univerzitet u Beogradu, 1980), 16-17.

15 Prpa-Jovanović, “Jugoslavija kao moderna država," 93. Cf. Bakić, Ideologije jugoslovenstva.

16 Prpa-Jovanović, "Jugoslavija kao moderna država," 378-379.

17 Milojković-Đurić, "Muzika kao deo srpske kulture," 195.

18 Prpa-Jovanović, "Jugoslavija kao moderna država," 172.

${ }^{19}$ See Petar Konjović, Miloje Milojević: kompozitor i muzički pisac [Miloje Milojević: Composer and Music Writer] (Belgrade: Srpska akademija nauka, 1954), 58-63.
} 
In addition to the first and most cited ball, The Thousand and Second Night, for which Milojević composed his ballet Sobareva metla and which is the only one documented in the archival records of the association, two more balls were held: Svadba u Skadarliji (A Wedding in Skadarlija) and Zlatni vek (The Golden Age). ${ }^{20}$ The Thousand and Second Night ball was organized on February 16, 1923, at a time when the administration of the Cvijeta Zuzorić Association was not yet operative and the organization was in the hands of Branislav Nušić, who worked in the Arts Department of the Ministry of Education. The idea for the event came from Rade Drainac, who witnessed the success of an art ball in Zagreb, and suggested that the ball be organized for the benefit of artists and writers. In consultation with Nušić and "several artists, writers and friends," the original idea was changed so that the funds raised would go for the construction of the Art Pavilion and the artists who took part received appropriate fees. Artists were paid 46,950 dinars (Milojević received 1,000 dinars), and 80,288 dinars were raised for the pavilion. ${ }^{21}$

Nušić invited an extremely large number of artists to the initial meetings for planning the ball-as many as 77-among whom were representatives of the most important institutions (such as the National Theatre), art schools, the press and several ministers. ${ }^{22}$ Notes from the meeting are preserved in the archives and include numerous suggestions regarding the contents of the soirée. Although most of these proposals were rejected, we can make certain conclusions about how the final content of the ball was shaped. The proposals most often imitated the avant-garde experiments of the Parisian art scene-one can find mentions of caricatures, imitations of cinema, etc. It is in these pages that we find the inception of the ballet Sobareva metla, which is mentioned for the first time as an "eccentric ballet of Ms. Isačenko". It is obvious that some of those present had information on Satie and Cocteau's ballet Parade, as one page of the notes has the following list jotted down: "7 record players, one typewriter, one siren-one Singer sewing machine-drum [...] saw, ocarina" 23 (see Figure 1). In other words, most of the non-musical sounds present in Satie and Cocteau's Parade were mentioned in the notes from this meeting. Thus, the connection between Sobareva metla and Parade, which these notes make clear, seems to have been conceived within the framework of joint artistic meetings. Besides describing the ballet as "eccentric," the notes also envisage the music to be composed as "futuristic." 24

\footnotetext{
${ }^{20}$ Krista Đorđević, “Osnivanje i delatnost Udruženja prijatelja umetnosti 'Cvijeta Zuzorić”" [The establishment and activities of the Cvijeta Zuzorić Association of Friends of Art], in Beograd u sećanjima: 1919-1929 (Belgrade: Srpska književna zadruga, 1980), 77.

${ }^{21} \mathrm{IAB}, \mathrm{CZ}, 4,4 \mathrm{j}$.

${ }^{22} \mathrm{IAB}, \mathrm{CZ}, 4 \mathrm{a}$.

23 “7 gramofona, jedna pisaća mašina, jedna sirena - jedna singerova šivaća mašina - bubanj [...] testeraš, okarina."

${ }^{24} \mathrm{IAB}, \mathrm{CZ}, 4$.
} 


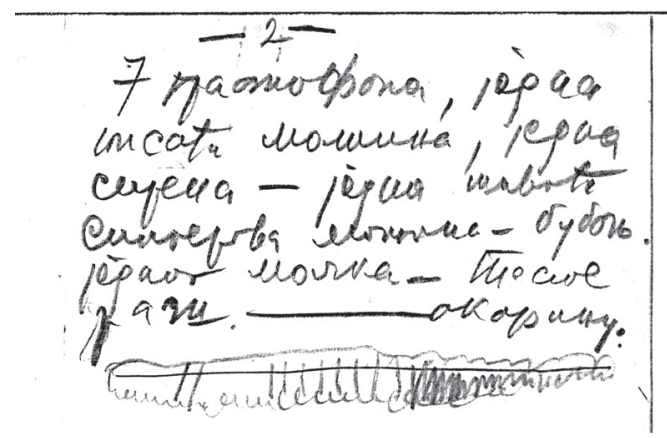

Figure 1. Fragment of the notes from the preparation of The Thousand and Second Night ball. IAB, CZ, 4 .

The notes from the artistic meetings in preparation of the soirée lead us to conclude that the avant-garde, collage structure of the ballet Sobareva metla is not merely Milojevićs intention, but a result of a kind of collective authorship. Belgrade's surrealist writers probably have the most credit for the avant-garde result itself, as this orientation was much more pronounced in their works than in those of contemporary Belgrade composers (of whom only Stanislav Binički and Milojević attended the meetings). If the poetics and concept of this ballet did not originate with Milojević, there is also little merit in interpreting this work as "a testimony to the early aspirations for experiment in Serbian music." ${ }^{25}$ On the contrary, it is a one-time influence, facilitated at a very specific sociopolitical moment, of avant-garde tendencies that were evolving in the contemporary literary field, and not a development within the field of music itself. Finally, The Thousand and Second Night ball in its entirety can be interpreted as an aspiration of the Belgrade political and artistic elite to present the achievements of the French avant-garde to the general public in Belgrade.

The artistic soirée raised great interest and was highly attended; the hall of Hotel Kasina, where it was held, was full and a provisional hallway was set up to connect it to the hall of Hotel Pariz next door to gain more space. ${ }^{26}$ The ball was of great importance for the initial positioning of the Cvijeta Zuzorić Association as an institution promoting modernist aspirations. However, it is also certain that the strong and broad official and institutional support, including from the National Theater and the Ministry of Education, somewhat blunted the edge of the avant-garde in the performances and reduced them to a kind of "cultured artistic event," in the words of Mirjana Veselinović-Hofman. ${ }^{27}$ The Thousand and Second Night ball was a distinct event for the interwar Belgrade society, in which

\footnotetext{
25 Milanović, “Sobareva metla," 262.

26 Đorđević, “Osnivanje i delatnost," 77.

${ }^{27}$ Mirjana Veselinović-Hofman, “Teze za reinterpretaciju jugoslovenske muzičke avangarde [Theses for the reinterpretation of the Yugoslav musical avant-garde]," Muzički talas 30-31 (2002): 25.
} 
avant-garde artistic practices-otherwise related primarily to poetry, as well as certain individual artists-were briefly institutionalized. ${ }^{28}$ It is within one such event, and owing to the sociopolitical conditions, that the unique transfer of postwar modernism to the field of music was achieved, which is indeed an extraordinary feat if we consider the demanding material conditions of musical production. ${ }^{29}$

\section{Modeling after impressionism: \\ Debussy, Milojevićs Plave legende and Bradićs String Trio}

As early as around 1925, we can notice a reaction to the avant-garde experiments, which were on the one side accused of being hermetic, overly intellectual and inaccessible, and on the other perceived as excessively emphatic, emotional and expressive. ${ }^{30}$ At the same time, the overall activities of Cvijeta Zuzoric Association of Friends of Art from 1923 to the end of the 1930s continued to be strongly marked by French cultural influence, in accordance with the cultural policy of the Kingdom of SCS/Yugoslavia. Thus, an exhibition of French graphics of the $17^{\text {th }}$ and $18^{\text {th }}$ centuries was held in 1926 in cooperation with the French-Serbian Club, which a letter to the Ministry of Education said was "organized for the purpose of French propaganda." ${ }^{11}$ The association then arranged an exhibition of French modern painters, in which "the best Parisian modern masters are to participate," and received 2,000 dinars from the ministry for this project. ${ }^{32}$

In the musical activities of the association, the French influence was manifested on the one hand in the French repertoire, and on the other hand in the first performances of works by Yugoslav authors written in the French manner. At the aforementioned exhibition in the hall of the French-Serbian Club, the association organized a matinée of $18^{\text {th }}$-century French art on March 8, 1926, which included performances of music by Jean-Baptiste Lully and Jean-Philippe Rameau. The programs of the association's musical events, including the activities of the National Conservatory, featured works by French composers such as Ernest Chausson, Camille Saint-Saëns, Vincent d'Indy, Claude Debussy, Philippe Gaubert and Gabriel Fauré. As we can see, "the French manner" no longer implied "eccentric" avant-garde experiments, as in case of The Thousand and Second Night ball, but above all what was seen as impressionism in music. Miloje Milojević, who was

\footnotetext{
${ }^{28}$ Cf. Bogdanović, "Slom posleratnog modernizma," 301.

${ }^{29}$ In this regard, it is also important to note that Milojević's ballet premiered from a piano score reduction, and that the work was only published in full as late as 1981.

${ }^{30}$ Prpa-Jovanović, "Jugoslavija kao moderna država," 170.

${ }^{31}$ Archives of Yugoslavia [Arhiv Jugoslavije (AJ)], Ministry of Education of the Kingdom of Yugoslavia [Ministarstvo prosvete Kraljevine Jugoslavije], 66-626-1034, Letter to the Ministry of Education for the purpose of obtaining customs relief, March 13, 1926.

32 AJ, 66-626-1034, Letter of president Olga Stanojević to the Ministry of Education, August 7, 1926.
} 
also one of the leading music writers of the period, explicitly voiced this position in his essay on impressionism, describing this style as quintessentially French, and noting that musical impressionism is an art that originates "on the French soil." 33

It is not suspiring that some of the most paradigmatic works of impressionism in Serbian music history were composed in direct connection to the Cvijeta Zuzorić Association of Friends of Art. ${ }^{34}$ The turn toward impressionism is probably best exemplified in the oeuvre of Milojević himself: just one year after Sobareva metla, Milojević presented his cycle Plave legende (Blue legends), op. 34, for piano and reciter, set to two poems by Jovan Dučić. The piece was performed for the first time at the concert of contemporary authors on February 17, 1924, and again at the concert of contemporary Yugoslav composers on March 17, 1926, both organized by the Cvijeta Zuzorić Association. ${ }^{35}$ Plave legende, subtitled as "poetic prose with piano accompaniment" (pesnička proza uz pratnju klavira), is characterized in musicological literature as completely and unambiguously Debussyan:

What dazzles in Milojevićs Plave legende is Debussyism, but Debussyism so complete and unambiguous that listening to the piece one could think that he or she is attending a performance of an unknown and newly discovered work by the French master. ${ }^{36}$

Dučić, a poet of a typically pro-French orientation, provided verses for another musical work related to the Cvijeta Zuzorić Association: Dubrovački rekvijem (The Dubrovnik Requiem) for mixed choir and soprano solo by Stevan Hristić, which was composed specifically for the occasion of the opening of the association's Art Pavilion on December 23, 1928. ${ }^{37}$ Once again, this work is recognized as an example of impressionism in Serbian music. ${ }^{38}$

However, the most open reference to French impressionism and Debussy, who already epitomized the style, was reached in the last phase of the association's musical

\footnotetext{
${ }^{33}$ Miloje Milojević, Muzičke studije i članci [Musical Studies and Articles], Vol. 3, edited by Gordana Trajković-Milojević (Belgrade: Izdavačka knjižarnica Gece Kona, 1953), 167.

${ }^{34}$ For a discussion on what constitutes and represents impressionism in Serbian music, see Valentina Radoman, Muzički impresionizam: elementi impresionističkog stila u srpskoj muzici prve polovine 20. veka [Musical Impressionism: Elements of the Impressionist Style in Serbian Music of the First Half of the $20^{\text {th }}$ Century] (Novi Sad: Akademija umetnosti, 2018), 96-146.

${ }^{35} \mathrm{IAB}, \mathrm{CZ}, 756,770$.

${ }^{36}$ Vlastimir Trajković, "Ključni opusi u stvaralaštvu Miloja Milojevića [Key opuses in the work of Miloje Milojević]," in Kompozitorsko stvaralaštvo Miloja Milojevića, edited by Melita Milin, Vlastimir Peričić (Belgrade: Muzikološki institut SANU, 1998), 21-22. The information dating Plave legende to 1927 in the same source obviously cannot be accurate.

${ }^{37}$ IAB, CZ, 43.

${ }^{38}$ Tijana Popović, "Elementi impresionističkog stila u stvaralaštvu Stevana Hristića [Elements of the impressionist style in the work of Stevan Hristić]," in Stevan Hristić i njegovo delo, edited by Vlastimir Peričić (Belgrade: Fakultet muzičke umetnosti, 1985), 42-69.
} 
activities, namely in its competitions for new Yugoslav compositions, and it was a work by a composer from Zagreb, Zvonimir Bradić, born in 1904 and a student of Blagoje Bersa. Responding to the second edition of the competition (1935), calling for new chamber music, Bradić submitted an elaborate and interpretatively demanding three-movement String Trio, the score of which has been preserved in the archive of the society. The jury consisted of three association members-Divna Popović, Nela Alkala and Mica Simić-and three composers from the music section of the association-Mihailo Vukdragović, Rikard Švarc and Kosta P. Manojlović. Selected from 28 submissions, Bradićs trio was awarded first prize, followed in second place by Antun Dobronićs Ballad for cello and piano and Mihovil Logar's song cycle Legenda $o$ Marku (The Legend of Marko). The jury did not provide an explanation for the decision in writing, but Manojlović and Vukdragović published an announcement for a concert of the awarded pieces, which was held on May 7, 1936:

Mr. Bradic's String Trio consists of three movements and confronts the performers with a difficult problem. The work is purely tonal and thematically elaborated, with freer harmonic progressions, impulsive rhythm and use of chromatics both in the theme and in harmony. In this respect, the theme $A$ from the first and second movements stands out. ${ }^{39}$

While using much more laudatory language to describe Logar's song cycle, Manojlović seems curiously reserved in praise of the winner of the competition. Similarly, Vukdragović provided only biographical data on Bradić in his announcement, adding that he would act as an "excellent representative of a solid composition school" established by Bersa, while delving into specific merits of Dobronićs and Logar's works. This wavering attitudes might stem from the fact that the jury judged the submitted works from the score, while the announcements were written when the performers were already ahead with their rehearsals. Music critics who attended the concert-Branko Dragutinović and Milenko Živković-were even more reserved toward Bradićs String Trio:

What catches the eye most in Zvonimir Bradic's String Trio is the agility in his treatment of instruments-a trait he obviously took from the excellent school of the late Blagoje Bersa. Apart from this, the lack of invention, the harmony that reaches a harsh hardness in his abandoning of all considerations of tonality, the tendency to expand the formal frameworks, leading to a dissolution of form-all of this results in Bradic's trio leaving a rather vague impression, despite some successful moments (especially the fugato at the beginning of the third movement). (B.D. $)^{40}$

\footnotetext{
$39 \mathrm{IAB}, \mathrm{CZ}, 785$.
}

40 Ibid. 
The String Trio of Z. Bradic lacks strong thematic invention; if those endless repetitions were omitted in a formal sense, this composition could act more directly. In our opinion, the second movement is formally the most compact. Surprisingly, the cello part is insufficiently developed throughout the trio. (M.Ž. ${ }^{41}$

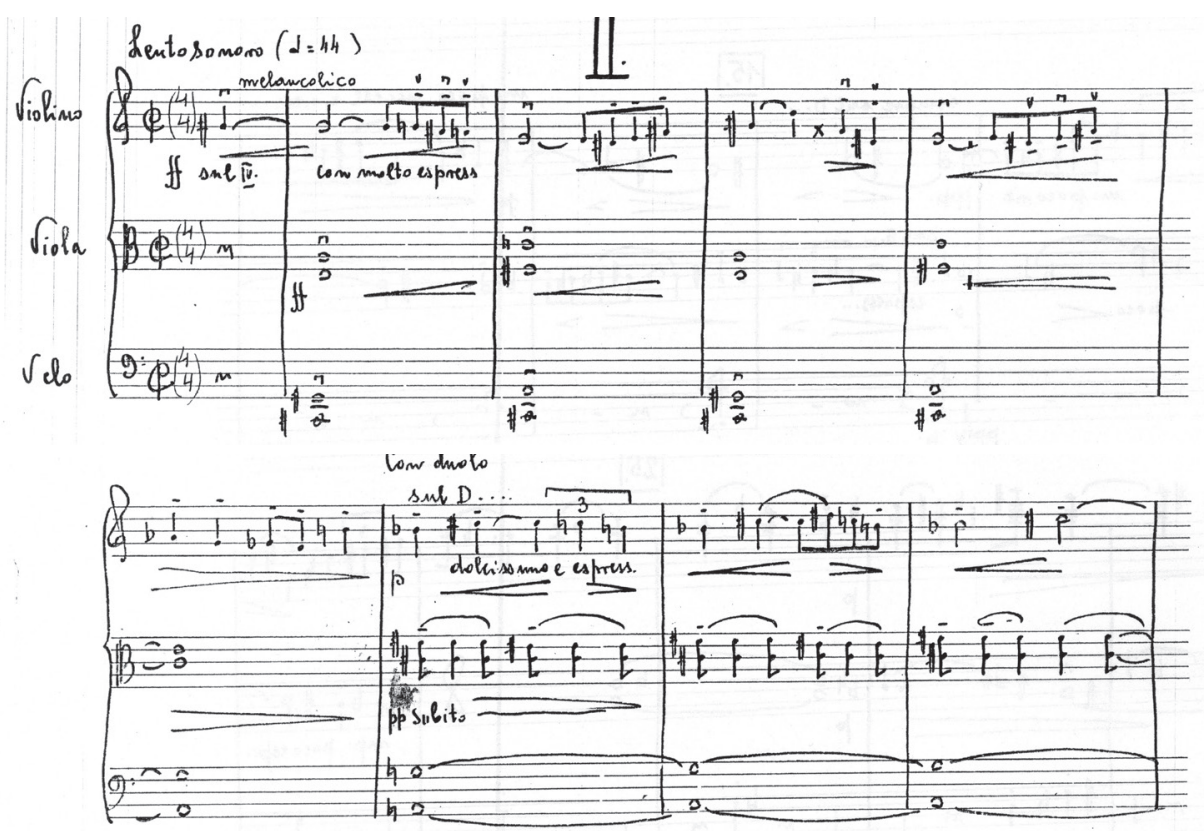

Figure 2. Zvonimir Bradić, String trio, $2^{\text {nd }}$ movement, Lento sonoro, m. 1-10. IAB, CZ, 785.

Très modéré

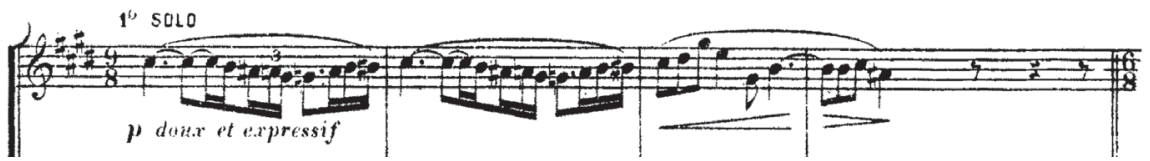

Figure 3. Claude Debussy, Prélude à l'après-midi d’un faune

(Paris: E. Fromont, 1895), flute part, m. 1-4.

${ }^{41}$ Ibid. 
In other words, there is a stark contrast between the laudatory first prize on one hand and the reserved statements by the jury members and mixed reviews by music critics on the other. This contrast might partially be explained by the score itself-it was the sole basis for the work of the jury. Surprisingly, the very beginning of the lyrical second movement, Lento sonoro, contains a direct citation of one of the most emblematic themes of musical impressionism: the opening of Claude Debussy's Prélude à l'après-midi d'un faune (1894). What could have served as a signal of political suitability of this chamber work is then used as the first subject of the lyrical Lento and the basis for thematic development (see Figure 2 and 3).

Based on the discussed cases, it is clear that the musical activities of the Cvijeta Zuzoric Association of Friends of Art strongly represented the official pro-French cultural policies of the Kingdom of Yugoslavia, at least up to mid-1930s, when the influence of France itself started to waiver and Yugoslavia was forced to reposition itself on the map of European alliances. There are, however, two important points which need to be additionally emphasized, and which are also important for understanding the broader musical scene of interwar Yugoslavia. Firstly, it is consequential to note that what we might interpret as influences of French music were-in the most prominent cases, such as Milojevićs Sobareva metla and Plave legende and Bradićs String Trio-clear and unequivocal modeling and quotations that would have been accessible and understandable to the educated audience of the Cvijeta Zuzorić Association. Secondly, it is clear that the perception of what was "French" regressed during this period from avant-garde art to academic impressionism. This change comes from both sociopolitical and professional reasons: the specific circumstances that enabled the encroachment of post-war modernism into music were short-lived, and professionalization and consolidation of the field of music became a priority. ${ }^{42}$ In the context of the Cvijeta Zuzorić Association of Friends of Art, this resulted in a seeming rise of conservatism and academism, which even competitions for new compositions designed to promote modern music could not fully address. The cutting edge of French influences, which in 1923 were epitomized by the likes of Erik Satie, Jean Cocteau and Sergei Diaghilev, was blunted and reduced in only a few years to the former glory of Claude Debussy, already deeply ingrained in musical academism.

\footnotetext{
${ }^{42}$ Cf. Tomašević, Na raskršću Istoka i Zapada; Vesić, Konstruisanje srpske muzičke tradicije; Ivana Vesić, Vesna Peno, Između umetnosti i života: o delatnosti udruženja muzičara u Kraljevini SHS/ Jugoslaviji [Between art and Life: On the Activities of Musicians' Associations in the Kingdom of SCS/Yugoslavia] (Belgrade: Muzikološki institut SANU, 2017).
} 


\section{Primary sources:}

Historical Archive of the City of Belgrade (IAB) (Belgrade): Cvijeta Zuzorić Association of Friends of Art
Archives of Yugoslavia (AJ) (Belgrade): Ministry of Education of the Kingdom of Yugoslavia

\section{References:}

Arnautović, Jelena. "Korak ispred vremena: dijalog Miloja Milojevića sa francuskim neoklasicizmom u baletu Sobareva metla." In Tradicija kao inspiracija, edited by Sonja Marinković, Sanda Dodik, 72-86. Banja Luka: Akademija umjetnosti, 2010. [Orig. in Serbian Cyrillic]

Atanasovski, Srđan. "Muzička delatnost Udruženja prijatelja umetnosti Cvijeta Zuzorić u kontekstu kulturne politike Kraljevine Jugoslavije." In Likovi i lica muz$i k e$, edited by Ivana Perković-Radak, Tijana Popović-Mlađenović, 207-224. Belgrade: Fakultet muzičke umetnosti, 2010. [Orig. in Serbian Cyrillic]

Bakić, Jovo. Ideologije jugoslovenstva izmedu srpskog $i$ hrvatskog nacionalizma 1918-1941: sociološko-istorijska studija. Zrenjanin: Gradska narodna biblioteka “Žarko Zrenjanin”, 2004.

Bogdanović, Milan. "Slom posleratnog modernizma." Danas 3 (1934): 300-311.

Calic, Marie-Janine. Geschichte Jugoslawiens im 20. Jahrhundert. Munich: Verlag C. H. Beck oHG, 2010.

Čalić, Mari-Žanin. Istorija Jugoslavije u 20. veku. Translated by Ranka Gašić and Vladimir Babić. Belgrade: Clio, 2013. [Orig. in Serbian Cyrillic]

Dimić, Ljubodrag. Kulturna politika u Kraljevini Jugoslaviji: 1918-1941. Politika i stvaralaštvo. Belgrade: Stubovi kulture, 1997. [Orig. in Serbian Cyrillic]
Đorđević, Krista, "Osnivanje i delatnost Udruženja prijatelja umetnosti 'Cvijeta Zuzorić"' In Beograd u sećanjima: 19191929, 76-83. Belgrade: Srpska književna zadruga, 1980. [Orig. in Serbian Cyrillic]

Janićijević, Milosav. Stvaralačka inteligencija međuratne Jugoslavije. Belgrade: Institut društvenih nauka, Centar za sociološka istraživanja, 1984.

Konjović, Petar. Miloje Milojević: kompozitor i muzički pisac. Belgrade: Srpska akademija nauka, 1954. [Orig. in Serbian Cyrillic]

Marković, Peđa J. Beograd i Evropa 1918-1941. Evropski uticaji na proces modernizacije Beograda. Belgrade: Savremena administracija, 1992.

Masnikosa, Marija. "Funkcija muzičkih simbola u kompozicijama Smrt majke Jugovića i Sobareva metla Miloja Milojevića." In Izuzetnost $i$ sapostojanje: $V$ medunarodni simpozijum Folklor, muzika, delo, edited by Miško Šuvaković, 140-145. Belgrade: Fakultet muzičke umetnosti, 1997. [Orig. in Serbian Cyrillic]

Milanović, Biljana. "Sobareva metla: bliskost s evropskom avangardom." In Kompozitorsko stvaralaštvo Miloja Milojevića, edited by Melita Milin, Vlastimir Peričić, 262-277. Belgrade: Muzikološki institut SANU, 1998. [Orig. in Serbian Cyrillic]

Milojević, Miloje. Muzičkestudije i članci. Vol. 3, edited by Gordana Trajković-Milojević. 
Belgrade: Izdavačka knjižarnica Gece Kona, 1953. [Orig. in Serbian Cyrillic]

Milojković-Đurić, Jelena. "Muzika kao deo srpske kulture u periodu između dva svetska rata.", $\mathrm{PhD}$ diss., Univerzitet u Beogradu, 1980.

Popović, Tijana. "Elementi impresionističkog stila u stvaralaštvu Stevana Hristića." In Stevan Hristić i njegovo delo. edited by Vlastimir Peričić, 42-69. Belgrade: Fakultet muzičke umetnosti, 1985.

Prpa-Jovanović, Branka, "Jugoslavija kao moderna država u viđenjima srpskih intelektualaca 1918-1929." PhD diss., Univerzitet u Beogradu, 1995.

Prpa, Branka. Srpski intelektualci i Jugoslavija: 1918-1929. Belgrade: Clio, 2018.

Radoman, Valentina. Muzički impresionizam: elementi impresionističkog stila $u$ srpskoj muzici prve polovine 20. veka. Novi Sad: Akademija umetnosti, 2018.

Tomašević, Katarina. "Prividni ili stvarni sukob Starog i Novog (vidovi sapostojanja tradicionalnog i modernog u srpskoj muzici između dva svetska rata)." In Izuzetnost $i$ sapostojanje: $V$ međunarodni simpozijum Folklor, muzika, delo, edited by Miško Šuvaković, 103-104. Belgrade: Fakultet muzičke umetnosti, 1997. [Orig. in Serbian Cyrillic]
Tomašević, Katarina. Na raskršću Istoka i Zapada. O dijalogu tradicionalnog i modernog u srpskoj muzici (1918-1941). Belgrade, Novi Sad: Muzikološki institut SANU, Matica srpska, 2009. [Orig. in Serbian Cyrillic]

Trajković, Vlastimir. "Ključni opusi u stvaralaštvu Miloja Milojevića." In Kompozitorsko stvaralaštvo Miloja Milojevića, edited by Melita Milin, Vlastimir Peričić, 18-30. Belgrade: Muzikološki institut SANU, 1998. [Orig. in Serbian Cyrillic] Veselinović-Hofman, Mirjana. “Teze za reinterpretaciju jugoslovenske muzičke avangarde." Muzički talas 30-31 (2002): 18-32.

Vesić, Ivana. Konstruisanje srpske muzičke tradicije u periodu izmedu dva svetska rata. Belgrade: Muzikološki institut SANU, 2018. [Orig. in Serbian Cyrillic]

Vesić, Ivana, Peno, Vesna. Između umetnosti i života: o delatnosti udruženja muzičara u Kraljevini SHS/Jugoslaviji. Belgrade: Muzikološki institut SANU, 2017. [Orig. in Serbian Cyrillic]

Vučetić, Radina. Evropa na Kalemegdanu. "Cvijeta Zuzorić" i kulturni život Beograda 1918-1941. Belgrade: Institut za noviju istoriju Srbije, 2003. [Orig. in Serbian Cyrillic] 